\title{
KEBERADAAN VISUM ET REPERTUM SEBAGAI PENDUKUNG PROSES PENYELESAIAN PERKARA TINDAK PIDANA PENGANIAYAAN YANG MENGAKIBATKAN KEMATIAN (Studi Kasus Putusan Nomor: 40/Pid.B/2013/PN.Olm)
}

\author{
Thasya Novianna \\ Fakultas Hukum Universitas Singaperbangsa Karawang \\ DOI : https://doi.org/ 10.29313/shjih.v19i1.7794
}

\begin{abstract}
ABSTRAK
Pemeriksaan suatu tindak pidana dalam proses peradilan hakekatnya untuk mencari sebuah kebenaran materil, salah satu caranya melalui Visum Et Repertum, yang berfungsi membuktikan adanya tindak pidana penganiayaan. Penelitian ini bertujuan untuk mengetahui faktor penyebab terjadinya penganiayaan dan mengetahui dan kedudukan Visum Et Repertum sebagai pendukung proses penyelesaian kasus tindak pidana penganiayaan yang mengakibatkan kematian. Penelitian ini termasuk penelitian yuridis normatif yang menggunakan data sekunder untuk menjawab permasalahan penelitian dengan teknis analisis kualitatif. Hasil penelitian menunjukan Visum et repertum membantu dalam membuktikan tindak pidana penganiyaan yang mengakibatkan kematian atau tindak pembunuhan. Berdasarkan kasus perkara Nomor: 40/Pid.B/2013/PN.Olm. Hakim dalam putusan Nomor: 40/Pid.B/2013/PN.Olm, Majelis Hakim mempertimbangkan berdasarkan keterangan ahli dalam Visum et repertum menilai korban meninggal akibat kemungkinan adanya pendarahan di bagian batang otak bagian belakang, akibat dari adanya trauma tumpul yang terjadi sekitar tengkuk belakang.
\end{abstract}

Kata kunci: Pembuktian, Penganiayaan, Visum et repertum.

\begin{abstract}
Examination of a crime in the judicial process is essentially to find a material truth, one way is through Visum Et Repertum, which serves to prove the existence of a
\end{abstract}


criminal act of persecution. This study aims to determine the factors that cause the occurrence of persecution and to find out and the position of Visum Et Repertum as a supporter of the process of resolving cases of criminal acts of persecution that resulted in death. This research includes normative juridical research that uses secondary data to answer research problems with qualitative analysis techniques. The results of the study show that Visum et repertum helps in proving criminal acts of persecution that result in death or murder. Based on case number: 40/Pid.B/2013/PN.Olm. The judge in his decision Number: 40/Pid.B/2013/PN.Olm, the Panel of Judges considered based on the expert testimony in Visum et repertum that the victim died due to possible bleeding in the back of the brain stem, as a result of blunt trauma that occurred around the nape of the neck. back.

Keywords: Verification, Torture, Visum Et Repertum.

\section{A. PENDAHULUAN}

Indonesia adalah negara hukum yang mana telah dinyatakan dalam pemahaman UUD 1945 "Negara Republik Indonesia berdasar atas hukum (rechstaat)", tidak berdasar atas kekuasaan belaka (machstaat). Dalam negara hukum, hukum ialah tiang utama dalam menggerakan kehidupan bermasyarakat, berbangsa serta bernegara.

Dalam artian suatu negara dengan konsep negara hukum senantiasa mengendalikan tiap tingkah laku masyarakatnya bersumber pada Undang- undang yang berlaku untuk menghasilkan, memelihara serta mempertahankan kedamaian hidup agar sama dengan apa yang diamanatkan dalam Pancasila serta UUD 1945 bahwa tiap masyarakat negara berhak atas rasa nyaman serta leluasa dari seluruh tindak kejahatan.

Hukum pidana merupakan hukum yang mengendalikan tentang pelanggaran-pelanggaran serta kejahatan-kejahatan terhadap kepentingan universal, perbuatan mana yang diancam dengan hukuman yang ialah sesuatu penderitaan ataupun siksaan. Perbuatan yang bisa menyebabkan hukum tindak pidana. Tindak pidana ialah perbuatan yang melanggar undang-undang, serta oleh 
karna itu berlawanan dengan undang- undang yang dengan terencana oleh orang yang bisa dipertanggung jawabkan tindakannya.

Maraknya tindakan penganiayaan salah satu fenomena yang ada didalam kehidupan bermasyarakat. Bermacam tindakan penganiayaan yang kerap terjadi seperti pemukulan serta kekerasan kerap kali menyebabkan luka pada bagian badan ataupun anggota badan pada korban, apalagi sering membuat korban menjadi cacat fisik seumur hidup sampai mengakibatkan kematian. Tidak hanya itu tindak penganiayaan pula sering memunculkan dampak ataupun akibat psikis pada korban seperti trauma, ketakutan, ancaman, apalagi terkadang terdapat korban penganiayaan yang dihadapi dengan gangguan jiwa serta mental. Tindak penganiayaan ini ialah sesuatu tindakan hukum yang bersumber dari suatu tindakan kesengajaan.

Kesengajaan ini merupakan akibat sesuatu perbuatan yang dikehendaki serta nyata, apabila akibat itu serius diartikan oleh perbuatan yang dicoba itu yang menimbulkan seorang mempunyai rasa sakit, luka, sehingga sampai memunculkan kematian hendak namun tidak semua perbuatan dengan memukul ataupun yang lain. Suatu masalah pidana didalam pembuktian sesuatu proses peradilan pada hakekatnya bertujuan untuk mencari kebenaran materil ialah kebenaran yang selengkap-lengkapnya dari sesuatu tindakan pidana dengan mempraktikkan ketentuan hukum acara pidana.

Dalam pemeriksaan perkara tindak pidana mulai dari penyidikan wajib terdapat pembuktian yang menguak tentang kesalahan dari seseorang terdakwa. Perkara tindakan penganiayaan dibutuhkan penjelasan pendapat ahli untuk membuat menguak sudah terjadinya tindakan penganiayaan yang dituangkan kedalam Visum Et Repertum. Salah satu alat bukti yang bisa digunakan penyidik untuk mengatakan tindak pidana penganiayaan yang menimbulkan orang meninggal dunia merupakan alat bukti surat.

Perlengkapan fakta pesan memanglah terdapat banyak jenisnya, salah satu antara lain merupakan laporan dalam bentuk tertulis yang terbuat oleh para ahli medis kedokteran kehakiman ataupun biasa diketahui dengan sebutan Visum Et Repertum atas permintaan yang berwenang, yang dibuat oleh dokter ahli, terhadap 
seluruh suatu yang ditemukan pada pengecekan alat bukti, yang bersumber atas sumpah pada saat menerima jabatan, dan bersumber pada pengetahuannya yang sebaik- baiknya.

Dalam usaha mendapatkan alat bukti yang dibutuhkan guna menguak kebenaran dari sesuatu perkara tindak pidana, sehingga kerapkali para penegak hukum meminta bantuan kepada seseorang ahli dalam rangka mencari kebenaran materil selengkap- lengkapnya untuk para penegak hukum tersebut. Visum Et Repertum ialah perlengkapan alat bukti yang sanggup mengungkapkan tubuh manusia yang menjadi korban dalam suatu tindak pidana.

Visum Et Repertum sekedar ialah laporan tentang apa yang dilihat serta ditemui, nampak dalam pengecekan raga tubuh manusia yang menggantikan alat bukti yang terdapat di tempat peristiwa terjadi perkara terdapat pada Pasal 187 KUHAP. Apabila di tinjau dari hukum acara pidana, penjelasan para ahli sangat dibutuhkan dalam tiap tahapan pengecekan baik dari tingkatan penyidikan, penuntutan ataupun pengecekan disidang pengadilan.

Vonis ataupun putusan perkara pidana bisa dijatuhkan kepada tersangka apabila ada sekurang-kurangnya dua perlengkapan alat bukti yang sah, dengan kepercayaan penuh dari hakim sebagaimana tertuang dalam KUHAP Pasal 183. Bisa berbentuk lama pidana penjara dipengaruhi oleh bermacam aspek, tercantum salah satunya merupakan kualifikasi luka yang mana tercantum di dalam Visum Et Repertum.

Visum Et Repertum sangat berarti dalam sesuatu perkara pidana khususnya untuk peristiwa matinya seorang yang disebabkan oleh penganiayaan yang dicoba dengan bermacam modus tindakan karena biasanya alat bukti saat kejadian tersebut tidak membolehkan untuk didatangkan dalam sidang. Untuk itu penulis tertarik untuk membahas bagaimana kedudukan Visum Et Repertum sebagai pendukung dalam penegakan hukum, khususnya terhadap tindak pidana penganiayaan yang mengakibatkan kematian pada korban? bagaimana pertimbangan hakim dalam menjatuhkan putusan terhadap pelaku tindak pidana penganiayaan yang menyebabkan matinya korban? 


\section{B. METODE PENELITIAN}

Penelitian ini menggunakan metode penelitian yuridis normatif yaitu metode penelitian yang dilakukan untuk menemukan kebenararan berdasarkan logika keilmuwan hukum dari segi normatifnya yang mengacu kepada norma-norma hukum yang terdapat dalam peraturan perundang-undangan, sejarah, kasus dan putusan pengadilan. Data yang digunakan dalam penelitian ini yaitu data yang diperoleh melalui penelitian kepustakaan dan teknik pengumpulan dan inventarisasi peraturan perundang-undangan, buku-buku, karya ilmiah, artikel-artikel yang yang berhubungan dengan produk permasalahan penelitian. 


\section{PEMBAHASAN}

\section{Kedudukan Visum Et Repertum Sebagai Pendukung Dalam} Penegakan Hukum Khususnya Terhadap Tindak Pidana Penganiayaan yang Mengakibatkan Kematian

Kejahatan telah terdapat semenjak manusia ada di lingkungan masyarakat, demikian pula cara untuk mengatasi segala permasalahan kejahatan ini sudah lama dilakukan oleh para ahli semenjak dulu kala. Kejahatan terhadap tubuh manusia diperuntukan untuk kepentingan hukum atas tubuh dari perbuatan-perbuatan berbentuk penyerangan atas tubuh manusia ataupun bagian dari tubuh manusia yang menyebabkan rasa sakit ataupun luka, apalagi terhadap luka yang terdapat pada tubuh bisa mengakibatkan kematian. Pencengahan maupun penanggulangan saja bukanlah cukup, diperlukan pula hal-hal untuk menghadapi kejahatan yang telah terjadi, untuk itu dibutuhkan ilmu pengetahuan semacam Visum Et Repertum untuk menolong memudahkan pengungkapan sesuatu permasalahan perkara tindak pidana kejahatan semacam penganiayaan.

Penganiayaan merupakan sesuatu perbuatan yang dicoba dengan terencana yang diperuntukan untuk memunculkan rasa sakit ataupun luka pada tubuh orang lain, yang dampaknya sematamata ialah sebuah tujuan dari seorang petindak. Sebagaimana sudah diketahui, dalam Kitab Undang-Undang Hukum Pidana (KUHP) didetetapkan perbuatan-perbuatan kejahatan serta pelanggaran yang dilakukan seseorang, yang oleh Moeljatno dikatakan selaku perbuatan pidana ataupun delik.

Faktor internal merupakan faktor-faktor yang ada pada seseorang, seperti: pertama faktor lemahnya iman ialah faktor yang sangat mendasar yang menimbulkan seseorang melaksanakan suatu kejahatan. Keyakinan, nilai, serta moral pengaruhi ungkapan marah orang dengan lingkungannya. Perihal ini berlawanan dengan norma yang bisa memunculkan kemarahan yang dimanifestasikan dengan rasa tidak 
berdosa. Orang yang yakin percaya kepada Tuhan senantiasa memohon bimbingan serta petunjuk kepadanya. Kedua faktor keluarga. Keluarga ialah lingkungan kelompok terkecil, apabila dibanding dengan kelompok-kelompok yang lain yang terdapat dalam lingkungan masyarakat. Meski demikian, lingkungan keluarga ialah lingkungan yang sangat berpengaruhnya dalam pembentukan prilaku seseorang. Ketiga faktor kejiwaan ialah watak khusus yang terdapat pada diri seseorang serta dititik beratkan pada segi psikologis seseorang. Permasalahan karakter kerap memunculkan kelakuan yang menyimpang terlebih lagi bila seseorang bisa dikategorikan tertekan perasaannya. Orang yang tertekan perasaanya memiliki kecenderungan melaksanakan tindakan penyimpangan, serta bisa jadi terhadap sistem sosial maupun terhadap pola- pola kebudayaan.

Faktor eksternal ini berawal dari lingkungan yang ada di luar dari seseorang yang melaksanakan tindakan yang menyimpang seperti tindakan penganiayaan. Pertama faktor ekonomi, dalam kehidupan tiap faktor ekonomi memegang peranan untuk memastikan arah hidupnya, Pergantian serta perbandingan dalam kesejahteraan sosial ekonomi memunculkan banyak konflik yang mendesak seseorang melaksanakan tindakan kejahatan. Tidak hanya faktor ekonomi, faktor lingkungan pun ialah salah satu faktor yang mempunyai pengaruh atas terbentuknya suatu tindak penganiayaan. Seorang yang hidup ataupun tinggal di dalam lingkungan yang mendukung dikerjakannya tindakan penganiayaan, hingga sewaktu waktu pun dapat melaksanakan tindak penganiayaan tersebut bersumber pada hasrat serta tujuan sipelaku.

Tidak bisa dipungkiri bahwa penganiayaan yang terjadi di lingkungan masyarakat, diakibatkan oleh banyak faktor, yang salah satunya merupakan faktor masyarakat khususnya ialah berbentuk sesuatu kondisi dimana keadaan masyarakat yang begitu mudahnya terprovokasi, sebab perkara yang mudah pun setelah itu dengan mudahnya memancing untuk membuat tindakan kekerasan dimana kekerasan yang terbentuk, dapat terjalin secara kolektif dengan mengaitkan komunitas ataupun kelompok tertentu di dalam masyarakat. 
Secara umum tindak pidana terhadap tubuh manusia didalam KUHP disebut penganiayaan. Penganiayaan sendiri berasal dari kata aniaya yang menampilkan subyek ataupun seorang yang melaksanakan penganiayaan itu menyebabkan sakit dan luka apalagi menimbulkan kematian terhadap orang lain ialah sesuatu tindakan penganiayaan, seperti melindungi keselamatan diri ataupun orang lain.

Untuk dapat mengenali bahwa seorang telah melaksanakan kejahatan tindakan penganiayaan apalagi hingga menimbulkan kematian, maka orang yang dituduh tersebut wajib mempunyai hasrat ataupun niat terencana untuk membuat rasa sakit ataupun cedera luka pada tubuh korban ataupun juga pelaku tersebut sudah mempunyai hasrat ataupun niat serta tujuan untuk merusak kesehatan orang lain. Seluruh tingkah laku ataupun suatu yang diperbuat oleh setiap orang wajib dipertanggung-jawabkan oleh masing- masing orang. Demikian pula dengan tiap tindakan penganiayaan yang sudah dilakukan. Tanggung jawab pidana merupakan tanggung jawab tiap orang ataupun seorang terhadap tindak pidana yang sudah dikerjakannya terhadap orang ataupun orang yang lain.

Tepatnya yang dipertanggung jawabkan orang itu merupakan seluruh tindak pidana yang diperbuatnya dalam perihal ini tindakan perbuatan penganiayaan. Hingga itu terbentuknya tanggung jawab pidana telah terdapat tindakan perbuatan kejahatan penganiayaan yang sudah dilakukan oleh seseorang. Pertanggungjawaban pidana pada hakekatnya ialah sesuatu mekanisme yang dibentuk oleh hukum pidana terhadap pelanggaran atas sesuatu perbuatan.

Dalam perkara tindak pidana pembuktian terdapat adanya tindak pidana yang dilakukan atas kesalahan tersangka. Dalam pembuktian perbuatannya diperoleh dari perlengkapan pada alat bukti minimum tentang terdapatnya tindak pidana yang diperbuat terdakwalah yang bersalah melaksanakan tindakan kejahatan serta pertimbangan kepercayaan hakim di persidangan. Guna pembuktian amat berarti sebab hendak jadi sandaran ataupun titik tolak vonis hakim. 
Supaya terbentuk pembuktian serta pelaksanaan pembuktian yang menghasilkan kepastian hukum serta keadilan, dibutuhkan ketentuan, kaidah, ataupun syarat sebagai pedoman. Kitab undang- undang hukum acara pidana (KUHAP) secara jelas sudah mengatur dengan alat bukti yang sah sesuai dengan yang diakui oleh undang- undang sebagaimana diatur dalam Pasal 184 KUHAP ialah:
a. Keterangan saksi
b. Keterangan ahli
c. Surat
d. Petunjuk
e. Keterangan terdakwa

Penjelasan keterangan saksi selaku alat bukti yakni orang yang bisa memberikan penjelasan guna kepentingan penyidikan, penuntut serta peradilan tentang sesuatu perkara pidana yang ia dengar sendiri, ia amati sendiri serta ia mengalami sendiri. Penjelasan keterangan ahli merupakan penjelasan yang diberikan oleh seseorang yang mempunyai kemampuan khusus pada bidangnya tentang perihal yang dibutuhkan untuk menguak sesuatu perkara pidana guna kepentingan pemeriksaan pembuktian. Ahli ialah seorang dokter kehakiman, dokter serta pakar ahli yang lain. Surat merupakan seluruh suatu yang memuat untuk mengantarkan pikiran seorang serta dipergunakan untuk salah satu pembuktian. Petunjuk merupakan perbuatan, peristiwa, ataupun kondisi, baik antara yang satu dengan yang lain, ataupun dengan tindak pidana itu sendiri, menunjukkan bahwa sudah terjadi sesuatu tindak pidana serta dengan siapa pelakunya.

Penjelasan tersangka yakni apa yang di nyatakan di persidangan tentang perbuatan yang ia lakukan ataupun yang dia tahu sendiri ataupun alami sendiri. Pada proses penyidikan perkara pidana yang menyangkut dengan tubuh, kesehatan serta nyawa manusia membutuhkan dorongan seseorang dokter ahli. Penjelasan yang diberikan oleh ahli medis kedokteran kehakiman disebut penjelasan keterangan ahli. 
Salah satu dari sekian banyak upaya serta sarana yang dilakukan oleh para dokter, ahli kedokteran kehakiman dalam menolong menguak sesuatu perkara pidana dari salah satu aspeknya merupakan"Visum Et Repertum" ialah diketahui dalam bidang ilmu kedokteran forensik. Visum et repertum selaku salah satu aspek peranan ahli ataupun salah satu aspek penjelasan ahli, hingga keterangan ahli yang tertuang dalam sesuatu laporan hasil pengecekan, merupakan perwujudan hasil- hasil yang bersumber pada atas ilmu serta metode dan pengetahuan serta pengalaman yang dicoba dari ahli kedokteran tersebut.

Ada beberapa kualifikasi cedera ringan, dan juga berat dapat dikenali lewat bagian kesimpulan dari Visum Et Repertum yang diungkapkan penjelasan yang terbuat oleh dokter ahli atas permintaan penyidik yang berwenang mengenai hasil dari pemeriksaan medik yang sudah dicoba kedokteran ahli terhadap manusia, baik hidup maupun mati, maupun bagian ataupun diprediksi bagian dari tubuh manusia, bersumber pada keilmuannya serta atas dasar sumpah untuk kepentingan peradilan. Visum Et Repertum selaku salah satu bukti yang sah didalam KUHAP Pasal 184 berfungsi sangat penting. Suatu masalah menjadi jelas dengan terdapatnya Visum Et Repertum yang menampilkan separah apa akibat yang terjalin dalam tindak pidana penganiayaan. Penyidik dalam melaksanakan penyidikan senantiasa membutuhkan dorongan seseorang ahli paling utama dalam menanggani kasuskasus penganiayaan serta mengakibatkan kematian. Pihak- pihak kejaksaan selaku penuntut umum walaupun tidak lagi mempunyai wewenang untuk melaksanakan penyidikan bukan berarti aparat kejaksaan mengenali hal- hal penyidikan. Mengenai penjelasan Visum Et Repertum itu pada biasanya polanya, dipecah dalam 3 bagian pokok ialah:
a. Bagian pendahuluan
b. Hasil pemeriksaan
c. Kesimpulan

Pengertian Visum et repertum ialah sesuatu laporan tertulis dari dokter ahli yang terbuat berdasarkan pada sumpah, Mengenai apa yang dilihat serta diketemukan 
atas bukti hidup, mayat maupun bukti lain, setelah itu dilakukan pemeriksaan bersumber pada pengetahuan. Atas dasar itu berikutnya diambil kesimpulan, dari seseorang dokter ahli secara tertulis, sebagaimana tertuang di dalam bagian pemberitaan hasil pemeriksaan.

Jenis Visum Et Repertum terdapat untuk orang hidup serta untuk orang mati.. Visum Et Repertum untuk orang mati, bisa dibedakan atas visum dengan pengecekan luar, serta dalam. Pengecekan mayat dicoba apabila terjadi sesuatu tindak pidana yang menyebabkan matinya seseorang. Visum et repertum mempunyai kedudukan strategi dalam memastikan tindak pidana yang terjadi. Apakah itu merupakan tindak pidana penganiayaan yang menyebabkan kematian ataupun pembunuhan. Perihal ini bisa dilihat dari jangka waktu kematian korban dengan waktu tindak pidana itu terjadi.

Apabila korban mati mendadak saat tindak pidana terjadi merupakan tindak pidana pembunuhan, sebaliknya apabila korban tidak mati mendadak saat tindak pidana terjadi, namun masih memiliki jangka waktu (misalnya masih mempunyai peluang untuk dibawa ke rumah sakit serta dokter masih pernah membagikan pertolongan) hingga tindak pidana yang terjadi merupakan tindakan pidana penganiayaan biasa yang menyebabkan kematian. untuk dapat melihat jangka waktu kematian bisa dilihat dari hasil Visum Et Repertum. Oleh karena itu, dapat disimpulkan bahwa Visum Et Repertum ialah penjelasan tertulis yang berisi kenyataan serta pendapat para keilmuan, yang terbuat oleh dokter ahli atas permintaan tertulis secara formal dari penyidik yang berwewenang jaksa serta hakim khusus untuk visum, tentang hasil pemeriksaan kedokteran, terhadap tubuh manusia, yang berdasarkan atas sumpah demi kepentingan peradilan.

II. Pertimbangan Hakim Dalam Menjatuhkan Putusan Terhadap Pelaku Tindak Pidana Penganiayaan Yang Menyebabkan Matinya Korban

Kasus posisi perkara No : 40/Pid.B/2013/PN.Olm : 
Kasus ini berawal ketika saksi Melvin Ataupah dan korban Ritnal Rasi datang Ponain hendak pulang menuju Apren dengan mengendarai sepeda motor Honda Supra X 125 yang dikemudikan oleh korban, karena hujan saksi Melvin Ataupah dan korban Ritnal Rasi berhenti di depan garasi mobil milik saksi Viktor Laku alias Cardoso untuk berteduh.

Setelah sepeda motor Honda supra x 125 berhenti saksi Melvin Ataupah langsung turun dari sepeda motor dan masuk ke garasi mobil milik saksi Viktor Laku alias Cardoso sedangkan korban Ritnal Rasi masih memarkirkan sepeda motor Honda supra $\mathrm{x}$ dipinggir jalan aspal. Karena melihat korban Ritnal Rasi terdakwa keluar dari dalam rumah saksi Viktor Laku alias Cardoso dan berjalan menghampiri korban Ritnal Rasi lalu terdakwa langsung memukul korban Ritnal Rasi sebanyak 1 (satu) kali dengan menggunakan tangan kanan mengenai pipi bagian kanan korban Ritnal Rasi lalu korban Ritnal Rasi menghindar dengan cara berlari meninggalkan terdakwa dan terdakwa mengejar serta mengambil sebatang kayu lamtoro kering yang berada didekat garasi mobil saksi.

Saksi Viktor Lakapu alias Cardoso kemudian langsung melemparkan kayu lamtoro kering tersebut kearah korban Ritnal Rasi dari jarak sekitar 5 (lima) meter dan mengenai kepala bagian belakang korban Ritnal Rasi sehingga korban Ritnal Rasi terjatuh keaspal dengan posisi tertelungkup. Pada saat korban Ritnal Rasi terjatuh, terdakwa datang mendekati korban dan menendang korban Ritnal Rasi sebanyak 1 (satu) kali kearah bagian dada sebelah kanan korban Ritnal Rasi sehingga korban langsung pingsan.

Akibat perbuatan Terdakwa korban dirawat di Puskesmas Oekabiti dan mengalami luka sebagaimana dalam Visum et Repertum Nomor 440.353 /42 /PKO / 2013 tanggal 28 Desember 2013 yang dibuat dan ditandatangani oleh dr. Anti. Pada tanggal 28 Desember 2012 pukul 20.13 wita, korban Ritna Rasi dirawat di RSUD Prof.Dr.W.Z.Yohanes Kupang hingga tanggal 29 Desember 2012 pukul 01.00 wita, sebagaimana Resume Medis dan perawatan Instalasi Gawat Darurat RSUD 
Prof.Dr.W.Z.Yohanes Kupang tanggal 14 Februari 2013 yang dibuat dan ditandatangani oleh dr. Rainoldy Wangi, MH.Kes.

Pergantian dokter jaga IGD berlangsung pukul 21.00 wita, pasien dirawat oleh dr. Rainoldy Wangi, MH.Kes dengan keadaan pasien masih sama seperti sebelumnya. Tanggal 29 Desember 2012 pukul 00.30 wita, keadaan umum pasien tiba-tiba menurun, kesadaran motorik 1 verbal 1 eye 1 dan pasien henti nafas, resusitasi jantung paru dengan obat-obatan selama setengah jam. Pasien dinyatakan meninggal pada tanggal 29 Desember 2012 pukul 01.00 wita, oleh dr. Rainoldy Wangi MH.Kes dihadapan keluarga. Perbuatan Terdakwa diatur dan diancam pidana sebagaimana dalam Pasal 351 ayat (2) KUHP. Menimbang, bahwa terhadap surat Dakwaan Penuntut Umum tersebut Penasihat Hukum maupun Terdakwa tidak mengajukan keberatan. Menimbang, bahwa untuk membuktikan dalil-dalil dakwaannya, Penuntut Umum telah menghadirkan saksi-saksi dipersidangan yang memberi keterangan dibawah sumpah sesuai tata cara agamanya masing-masing.

Setelah mendengar keterangan 6 orang saksi di persidangan dalam menjelaskan kesaksiannya. menimbang bahwa dipersidangan Penuntut Umum juga mengajukan bukti Surat berupa, Visum Et Repertum Nomor 440.353 /42/PKO / 2013 tertanggal 28 Desember 2012, Rujukan Medik Nomor 440.443/263/PKO / 11 tertanggal 28 Desember 2012 Surat keterangan Nomor 33/812.2/445/2013, tertanggal 25 Januari 2013, Surat Resume Medis dan perawatan instalasi Gawat Darurat RSUD Prof. Dr. W.Z.Yohanes Kupang, tertanggal 14 Februari 2013.

Menimbang, bahwa bukti -bukti surat tersebut dipersidangan telah dibacakan dan atas pembacaan bukti surat tersebut saksi-saksi maupun Terdakwa membenarkan. Pertimbangan Majelis Hakim. Menimbang, bahwa oleh karena dakwaan Penuntut Umum bersifat alternatif dan dilihat dari hasil Visum et repertum Nomor 440.353 /42/PKO / 2013 tertanggal 28 Desember 2012 , surat Rujukan Medik Nomor 440.443/263/PKO / 11 tertanggal 28 Desember 2012 , Surat keterangan Nomor 33/812.2/445/2013, tertanggal 25 Januari 2013 dan Surat Resume Medis dan 
perawatan instalasi Gawat Darurat RSUD Prof. Dr. W.Z.Yohanes Kupang, tertanggal 14 Februari 2013.

Bahwa berdasarkan keterangan ahli dan bukti-bukti surat tersebut maka korban meninggal akibat kemungkinan adanya pendarahan di bagian batang otak atau otak bagian belakang, akibat dari adanya trauma tumpul yang terjadi sekitar tengkuk belakang. Menimbang, bahwa Terdakwa diajukan kepersidangan berdasarkan surat Dakwaan Penuntut Umum yang tersusun secara Alternatif yaitu, Kesatu Perbuatan ia Terdakwa sebagaimana diatur dan diancam pidana dalam Pasal 351 ayat (3) KUHP. Atau kedua Perbuatan ia Terdakwa sebagaimana diatur dan diancam pidana dalam Pasal 351 ayat (2) KUHP.

Menimbang, bahwa oleh karena surat Dakwaan Penuntut Umum disusun dalam bentuk Alternatif maka berdasarkan konsekwensi hukum acara pidana maka dakwaan tersebut memberikan opsi/pilihan kepada Majelis untuk memilih dakwaan yang tepat yang dipertanggungjawabkan kepada terdakwa sehubungan dengan fakta hukum dipersidangan, berdasarkan hal itu maka Majelis Hakim memilih dakwaan pertama Penuntut Umum yaitu Pasal 351 (3) KUHP yang unsur-unsurnya satu Unsur Barang Siapa, kedua Unsur Penganiayaan yang mengakibatkan matinya orang.

Menimbang, bahwa yang dimaksud dengan barang siapa adalah menunjuk pada subyek hukum pendukung hak dan kewajiban serta kepadanya dapat dipertanggungjawabkan atas apa yang diperbuatnya. Menimbang bahwa yang dimaksud Penganiayaan yang mengakibatkan matinya orang Undang-Undang tidak memberi ketentuan apakah yang diartikan dengan "Penganiayaan" (mishandeling) itu, Menurut Yurisprudensi "Penganiayaan" yaitu sengaja menyebabkan perasaan tidak enak (penderitaan), rasa sakit (pijn), atau luka atau dapat mengakibatkan kematian. 
Pasal 351 ayat (3) KUHP tersebut memberikan pengertian apabila mengakibatkan kematian dan kematian itu bukan maksud dari pelaku tetapi merupakan akibat dari perbuatan pelaku. Menimbang, bahwa berdasarkan fakta hukum tersebut diatas maka Majelis berpendapat dan berkeyakinan kematian korban merupakan akibat dari perbuatan terdakwa yang melemparkan kayu dan mengenai tengkuk belakang korban dengan demikian unsur penganiayaan yang mengakibatkan mati tersebut di atas telah terpenuhi.

\section{PENUTUP}

1. Tindak pidana penganiayaan yang mengakibatkan kematian bukan menjadi tujuan yang dikehendaki. Oleh sebab itu kematian ini bukan sebagai unsur atau syarat untuk terjadinya penganiyaan berat akan tetapi menjadi faktor pemberat sanksi pidana pada penganiyaan berat. Visum et repertum merupakan keterangan tertulis yang berisi fakta dan pendapat berdasarkan keahlian/keilmuan, yang dibuat oleh dokter atas permintaan tertulis (resmi) dari penyidik yang berwenang memiliki kedudukan sebagai alat bukti yang sah yang menjelaskan penyebab kematian seseorang dan membantu penegak hukum dalam pengungkapan tindak pidana penganiayaan.

2. Dalam studi kasus putusan Nomor: 40/Pid.B/2013/PN.Olm, Majelis Hakim mempertimbangkan berdasarkan keterangan ahli dan bukti-bukti surat tersebut maka korban meninggal akibat kemungkinan adanya pendarahan di bagian batang otak atau otak bagian belakang, akibat dari adanya trauma tumpul yang terjadi sekitar tengkuk belakang. Hal ini menunjukan bahwa hakim telah mempertimbangkan Visum et repertum sebagai dasar memutus tindak pidana penganiayaan yang mengakibatkan kematian.

Seorang dokter yang diberikan wewenang undang-undang untuk melaksanakan pemeriksaan terhadap korban kejahatan, diharapkan untuk berlaku objektif sesuai dengan sumpah jabatan dokter kerena penjelasan pemeriksaan tersebut memberikan pengaruh dalam pembuktian, sehingga menghasilkan keterangan yang objektif untuk kepastian pembuktian dalam pengungkapan perkara dan memberikan kebenaran materiil. Peran Visum Et Repertum dalam pembuktian tindak pidana 
penganiayaan sangat penting, oleh karena itu penegak hukum khususnya penyidik sebaiknya membantu menyelesaikan perkara penganiayaan dengan permintaan pembuatan Visum Et Repertum kepada ahli kedokteran untuk memudahkan penyelesaian perkara pidana yang sedang ditangani. 


\section{DAFTAR PUSTAKA}

\section{A. Buku}

Chazawi, A. Kejahatan Terhadap Tubuh dan Nyawa. PT. Raja Grafindo Persada. Jakarta: 2001.

Kansil. Pengantar Ilmu Hukum dan Tata Hukum Indonesia. Balai Pustaka. Jakarta, 2013.

Moeljatno. Asas-Asas Hukum Pidana. Jakarta: Rineka Putra, 2008.

Njowito Hamdani, Ilmu Kedokteran Kehakiman, Gramedia Pustaka Tama, jakarta: 1992.

R. Atang Ranoemihardja, Ilmu Kedokteran Kehakiman (Forensic Science), Edisi kedua, Tarsito Bandung: 1983.

Tjiptomartono Agung Legowo, Penerapan Ilmu Kedokteran Kehakiman Dalam Proses Penyidikan, Karya Unipres, Jakarta, 1982.

Waluyadi, Ilmu Kedokteran Kehakiman Dalam Perspektif Peradilan dan Aspek Hukum Praktik Kedokteran, Djambatan, Jakarta: 2000.

\section{B. Jurnal}

Afandi, Dedi. Visum Et Repertum Perlukaan: Aspek Medikolegal Dan Penentuan Derajat Luka. Majalah Kedokteran Indonesia, Volume: 60 Nomor: 4 April 2010.

Budi, Sampurna. Peranan Ilmu Forensik Dalam Penegakan Hukum. FK UI. Jurnal Fiat Justisia. Vol 10, No. 3, 2016.

Fatriah, Syarifah Hidayah, Budi Sampurna, Ade Firmansyah Sugiharto. "Analisis Medikolegal Terhadap Kriteria Derajat Luka Menurut Kitab Undang-Undang Hukum Pidana. Majalah Kedokteran Indonesia, Vol 67, No. 11, November 2017.

Gagundali, Deysky Neidi, Visum Et Repertum Sebagai Alat Bukti Dalam Perkara Tindak Pidana Penganiayaan Ringan Menurut Kitab Undang-Undang Hukum Acara Pidana', Lex Administratum, Vol.9 2017. 
Yusup Khairun Nisa, Johny Krisnan, Kekuatan Visum Et Repertum Sebagai Alat Bukti Dalam Mengungkap Terjadinya Tindak Pidana”, Varia Justicia: No 2 Vol 11 No. 2 Oktober 2015.

\section{Perundang-undangan}

Undang - Undang Dasar Negara Kesatuan Republik Indonesia Tahun 1945

Kitab Undang - Undang Hukum Pidana

Kitab Undang - Undang Hukum Acara Pidana 